\title{
イルメナイトーヘマタイト系固溶体の生成に 関する基礎的研究*
}

\author{
下飯坂潤三 ${ }^{1}$ 中塚勝人” \\ 武田 進 ${ }^{3}$ 長谷部 茂
}

\section{1. 緒言}

$\mathrm{FeO}-\mathrm{Fe}_{2} \mathrm{O}_{3}-\mathrm{TiO}_{2}$ 系鉱物には 3 種の固溶体が存在する。 すなわち, $\mathrm{Fe}_{2} \mathrm{TiO}_{4}-\mathrm{Fe}_{3} \mathrm{O}_{4}$ 系列 (Ulvöspinel-Magneti te), $\mathrm{FeTiO}_{3}-\mathrm{Fe}_{2} \mathrm{O}_{3}$ 系列 ( I Imen i te-Hema ti te), $\mathrm{Fe}_{2} \mathrm{Ti}_{2} \mathrm{O}_{5}-$

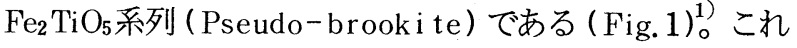
らのうち,イルメナイトーヘマタイト系固溶体 $\left(x \mathrm{FeTiO}_{3}\right.$. $\left.(1-x) \mathrm{Fe}_{2} \mathrm{O}_{3}\right)$ は端成分鉱物のイルメナイトおよびへマタ イトが, それぞれ常温で常磁性および反強磁性であるにも かかわらず中間のある組成範囲でフェり磁性を示すことが しられており,これまでに多くの研究例が報告されている。 Nagata らは天然扝よび人工のイルメナイトーヘマタイト 系固溶体の磁性に関する研究を行ない, 天然鉱物では 0.5 $<x<0.85$ の組成範囲の固溶体が存在するが,人工的には $1050{ }^{\circ} \mathrm{C}$ 以上であればすべての組成にわたつて固溶体が合 成できること, $0.55<x<0.7$ には強磁性が, $0 \leqq x<0.5$ に は弱い強磁性があらわれること, および，固溶体のキュリ 一温度はへマタイトの $670^{\circ} \mathrm{C}$ からイルメナイト組成に近づ くとともに直線的に低下することなどを報告している。 さ らに Ishikawaらは人工試料について検討し磁性を結晶の 対称性すなわちR $\overline{3}(0.45 \leqq x<1)$ および $\mathrm{R} \overline{3} \mathrm{C}(0 \leqq x$ $\leqq 0.6$ ）に分けて考光，強磁性はチタンを多く含むR $\overline{3}$ 構造 によるものであること, $0.45 \leqq x \leqq 0.6 に お け る R \overline{3}-\mathrm{R} \overline{3} \mathrm{C}$ 転移は可逆的に抗こること, および，その転移温度はイル メナイトの組成 $(x)$ が増すとともに上昇することなどを見 い出している。

一方, イルメナイトーヘマタイト系固溶体の生成に関す る研究もいくつか報告されている。平社らはアーク溶融法 による同系列の鉱物の合成実験を行ない，イルメナイトヘマタイト系固溶体は $\frac{2}{3} \leqq x \leqq 1$ でのみ合成できることを 報告している。 Carmichael ${ }^{8)}$ およびUyeda ${ }^{9}$ らは天然の ヘマタイトとイルメナイトを用いて固溶線(Solvus curve) について調べ, 固溶線はほぼ中間組成で最高となり $950^{\circ} \mathrm{C}$ 付近に存在するとしている。これに対しLindhは熱水合成 法によれば固溶線の最高温度は $660^{\circ} \mathrm{C}$ 付近に存在し $550^{\circ} \mathrm{C}$ 以上ではマグネタイトとルチルが安定に存在することを報

* 1978 年 9 月 29 日受理 昭和 53 年 4 月日本鉱業会春季大会にて一 部発表

1. 正会員 工博 東北大学教授 工学部資源工学科

2. 正会員 I博 東北大学助教授 I学部資源工学科

3. 正会員 東北大学助手 選鉱製鍊研究所

4. 正会員 工博 岩手大学教授 工学部資源工学科

a） Fe あるいは Ti が固体内を拡散し均一な固溶体が形成される温度を 固溶体の組成此と温度の関係として示したもの。
告している。

以上のようにイルメナイトーヘマタイト系固溶体の生成に 関して種々の研究が報告されているが，まだ未知な点も 多く, 特に低温域 $\left(500 \sim 1000^{\circ} \mathrm{C}\right)$ での生成過程に関して より定量的に検討することが必要であると考えられる。こ のような観点から, 本研究は封入法 (シリカガラス管)を 用いイルメナイトーヘマタイト系固溶体の生成におよぼす 組成および温度の影響を検討したものである。

\section{2. 実験試料および実験方法}

出発試料としては市販の一級試薬四三酸化鉄 $\left(\mathrm{Fe}_{3} \mathrm{O}_{4}\right)$, 酸化第二鉄 $\left(\mathrm{Fe}_{2} \mathrm{O}_{3}\right)$ ，二酸化テタン $\left(\mathrm{TiO}_{2}\right)$ を用いた。ま ず, 四三酸化鉄を雾囲気 $\mathrm{CO}: \mathrm{CO}_{2}=2: 1(80 \mathrm{ml} / \mathrm{min}: 40$ $\mathrm{ml} / \mathrm{min})$ のもとでシリコニット電気炉にて $900^{\circ} \mathrm{C}, 3$ 時 間焼成してウスタイトを作成した。この試料のX線回折図 形は完全にウスタイトのみが生成していることを示してい た。 $900^{\circ} \mathrm{C}, P_{\mathrm{O}_{2}}=1.99 \times 10^{-17}$ で得られるウスタイトの 組成は $\mathrm{Fe}_{0.92} \mathrm{O}$ 付近にあると考えられる。 タイトと二酸化チタン試薬を $1 ： 1$ に秤量し自動擂潰機に て 1 時間混合粉砕したのち, 雾用気を同じく $\mathrm{CO}: \mathrm{CO}_{2}=$ $2: 1(80 \mathrm{ml} / \mathrm{min}: 40 \mathrm{ml} / \mathrm{min})$ として $1150^{\circ} \mathrm{C}, 3$ 時間 焼成してイルメナイトを作成した。本試料のX線回折図形 もイルメナイトのみであつた。

固溶体の作成は，まずイルメナイトとへマタイトを目的 組成となるよう科量し, 自動擂潰機にて 30 分混合粉砕後 石英管中に入れ, 油拡散式真空ポンプにて $10^{-3} \mathrm{mmHg}$ 以 下に吸引, 封入し, このアンプルを所定温度 $\left( \pm 10^{\circ} \mathrm{C}\right)$ に て一定時間焼成後水中に投入して急冷した。

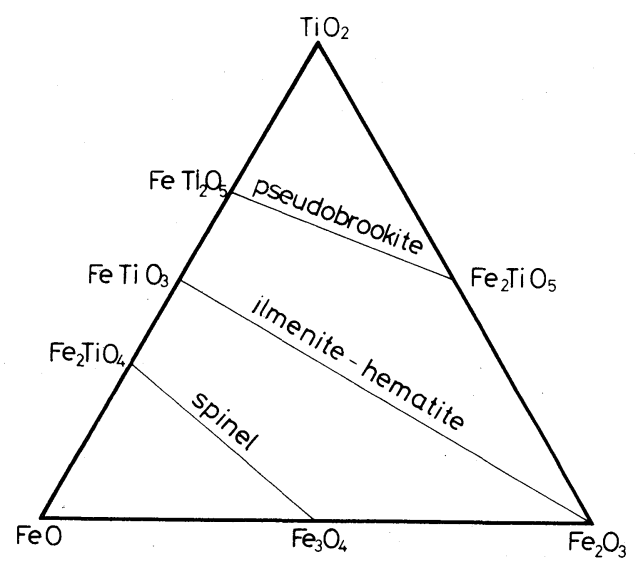

Fig. 1 Phase diagram of $\mathrm{FeO}-\mathrm{Fe}_{2} \mathrm{O}_{3}-\mathrm{TiO}_{2}$ system.

日本鉱業会誌/961114 ('80-12) $857<1>$ 

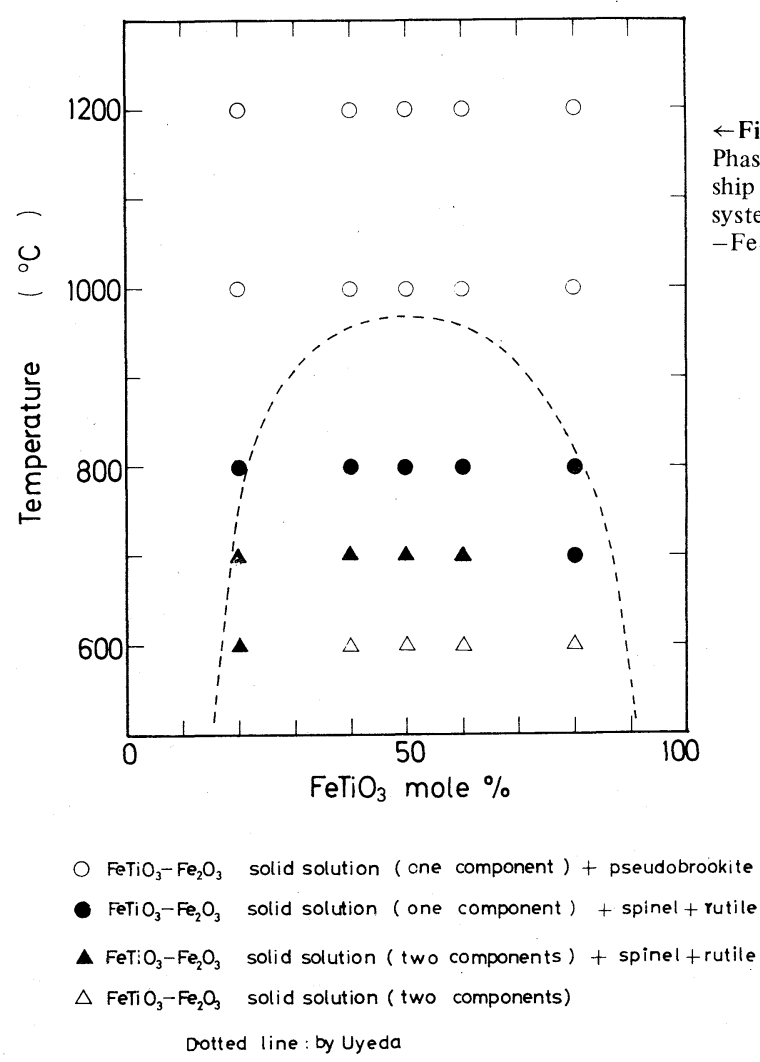

試料粉末のX線回折および格子定数の測定には理学電機 XGC-30を用い，X線管球には Co を用いた。X線回折は $30 \mathrm{kV}, 20 \mathrm{~mA}$, 時定数 2 秒, スキャニング速度 $1 \% \mathrm{~min}$ で，また，格子定数の測定は $35 \mathrm{kV}, 20 \mathrm{~mA}$, 時定数 20 秒，スキャニング速度 $1 / 16 \%$ min で操作した。角度は高 純度 $\mathrm{Si}$ を標準物質として補正した。磁性の測定には成瀬科 学製広根式自動計測型磁気天科を用いた。

\section{3. 実験結果および考察}

Fig. 2 は各組成に調合したイルメナイトーヘマタイト混 合試料 $\left(x \mathrm{FeTiO}_{3}+(1-x) \mathrm{Fe}_{2} \mathrm{O}_{3}\right)$ を種々の温度で 6 時間 加熱したのちの焼成物についてX線回折より同定された相

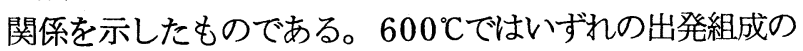
試料についても, 得られるイルメナイトーへマタイト系固 溶体の稠密六方のX線回折図形は明らかに二つの異なる組 成のものからなることを示しており , 反応忙初期段階にあ ると考えられる。ただ， $x=0.2$ ではスピネルおよびルチ ルが共生しているのが認められた。7000でも各試料は組 成の異なる二つの固溶体からなるが, $600^{\circ} \mathrm{C} の$ 場合に比し て同一面指数に相当する回折線は互いに近づく傾向にあり， この焼成温度ではイルメナイトとへマタイトの固溶はある 程度進行している。とくに $x=0.8$ の出発組成のものは組 成の均一な固溶体とみなせる。また，いずれの組成の試料 にもスピネルおよびルチルが生成していることが認められ るが，それらの量は組成により異なり，イルメナイト組成 $(x)$ の小さい $x=0.2 \sim 0.4$ で比較的多量のスピネルおよ

b) 格子定数の測定の結果, イルメナイトに近い組成とへマタイトに近 い組成の固溶体が生成しているのが認められた。

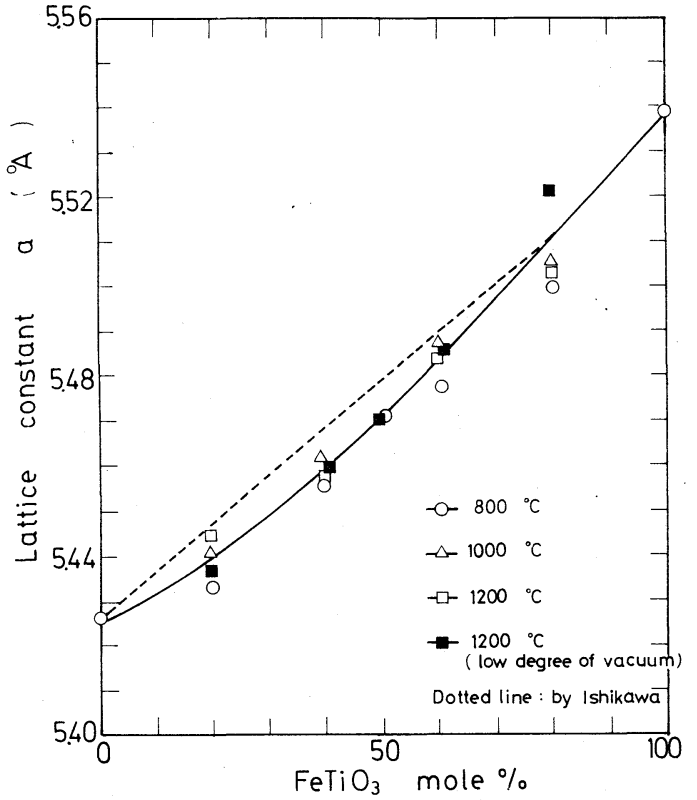

びルチルが生成しているのに対し， $x=0.8$ 付近ではその 量はきわめて少ないことが認められた。 $800^{\circ} \mathrm{C} の$ 場合には いずれの出発組成の場合にも回折線は単一のピークからな つておりイルメナイトとへマタイトの固溶は終期段階にあ ると考えられる。ただし，いずれの組成の試料にもスピネ ルおよびルチルが残存しているのが認められ，この傾向は 特に $x=0.2 \sim 0.4$ で顕著で, $x=0.8$ 付近ではきわめて 僅かである。1000, $1200^{\circ} \mathrm{C}$ ではいずれの出発組成の場 合にも回折線は 1 種類の稠密六方図形のみからなり,一つ の組成の固溶体が生成しているものと考えられる。 お，スピネルおよびルチルの生成は認められないが，いず れの組成の試料にも若干の Pseudo-brook i te 系固溶体が 生成しており, この傾向は特にイルメナイト組成 $(x)$ の大 きい $x=0.8$ 付近で顕著である。すなわち, 本実験によれ ばイルメナイトーヘマタイト系連続固溶体は $800^{\circ} \mathrm{C}$ 以上で 生成するものと思われる。一方, Fig. 2 中の点線はUyeda により天然試料について得られたこの系の固溶線 ( solvus curve)である。これによれば $800^{\circ}$ Cで゙は出発組成が 0.22 $<x<0.82$ の範囲では 2 成分の固溶体が生成すると考えら れる。このように, 著者らの結果がUyedaの結果と異なる のは出発試料すなわち天然試料と人工試料の差違のためと 考えられる。

Fig. 3 は連続固溶体を生成する 800,1000 ，および $1200^{\circ} \mathrm{C}$ の 6 時間焼成物の格子定数を測定した結果を示し たものである。同図には Ishikawaらにより得られた結果 を付記した。また，比較のために真空度の劣る場合の例と してアンプルをアスピレータで吸引, 封入後, $1200^{\circ} \mathrm{C}$ で同時間焼成した結果も示したが，結果はほとんど真空度 の影響を受けておらず封入が完全であれば生成雾囲気は出 発酸化物の混合比でほとんどきまつてしまうことがわかる。 格子定数はいずれも Ishikawaらの得た值 ${ }^{5)}$ にほぼ一致し,

c）天然試料を十分混合粉砕してないことも異なる結果を得る原因の一 つと考えられる。10) 
イルメナイト組成 $(x)$ が増すとともにへマタイトの 5.426 丸からイルメナイトの $5.539 \AA$ までなだらかな曲線上を連 続的に増加する。なお，組成と格子定数の関係が下に凸の 曲線となるのは $800^{\circ} \mathrm{C} て ゙$ 焼成した場合には後述するように イルメナイトーヘマタイト系固溶体の生成のほかにイルメ ナイトの一部が分解してマグネタイトとルチルを生成する ために，また 1000 ，および $1200{ }^{\circ} \mathrm{C}$ で焼成した場合には イルメナイトーヘマタイト系固溶体の生成のほかにPseudo - brooki te 系固溶体が生成するためdに結果としてチタン の不足したイルメナイトーへマタイト系固溶体が生成する ことに原因があると考えられる。

前述のように $800{ }^{\circ} \mathrm{C}$ 以下ではイルメナイトーヘマタイ ト系固溶体にスピネルおよびルチルが共存するが，つぎに これら固溶体の生成におよぼす焼成時間の影響を検討した。 Fig. 4 は出発組成 $x=0.4$ の試料を $700^{\circ} \mathrm{C}$ て種々の時間焼 成したときの試料のX線回折図を示したものである。同図 には比較のために $600^{\circ} \mathrm{C}, 6$ 時間焼成したときの結果も付 記した。 $2 \theta=75.1^{\circ}$ および $76.0^{\circ}$ にあるイルメナイトと へマタイトの ( 300$)$ 面のピークは時間の経過とともに互い に $2 \theta=75.7^{\circ}$ の方向に近づき, 固溶の進行する過程を示 している。また,イルメナイトとへマタイトの $(214)$ 面 のピークも時間の経過とともに互いに近づき, 60 時間の焼 成の後には $2 \theta=73.7^{\circ}$ 付近のイルメナイトーへマタイト 系固溶体の (214) 面の回折線となる。なおこの祭, $2 \theta=$ $74.1^{\circ}$ にスピネル相の $(440)$ 面の回折線が生ずる。これ がへマタイトの (214) 面でないことは(5)において $76.0^{\circ}$ のへマタイトの (330) 面が消失していることから明らか

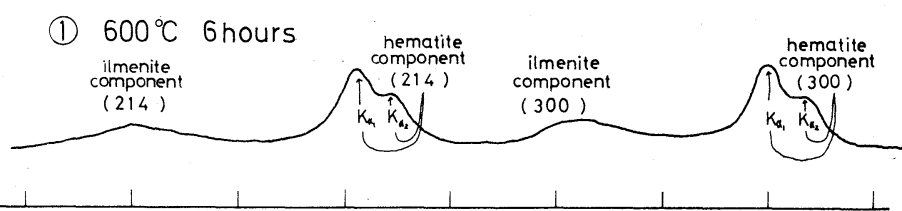

(2) $700^{\circ} \mathrm{C}$ 6hours
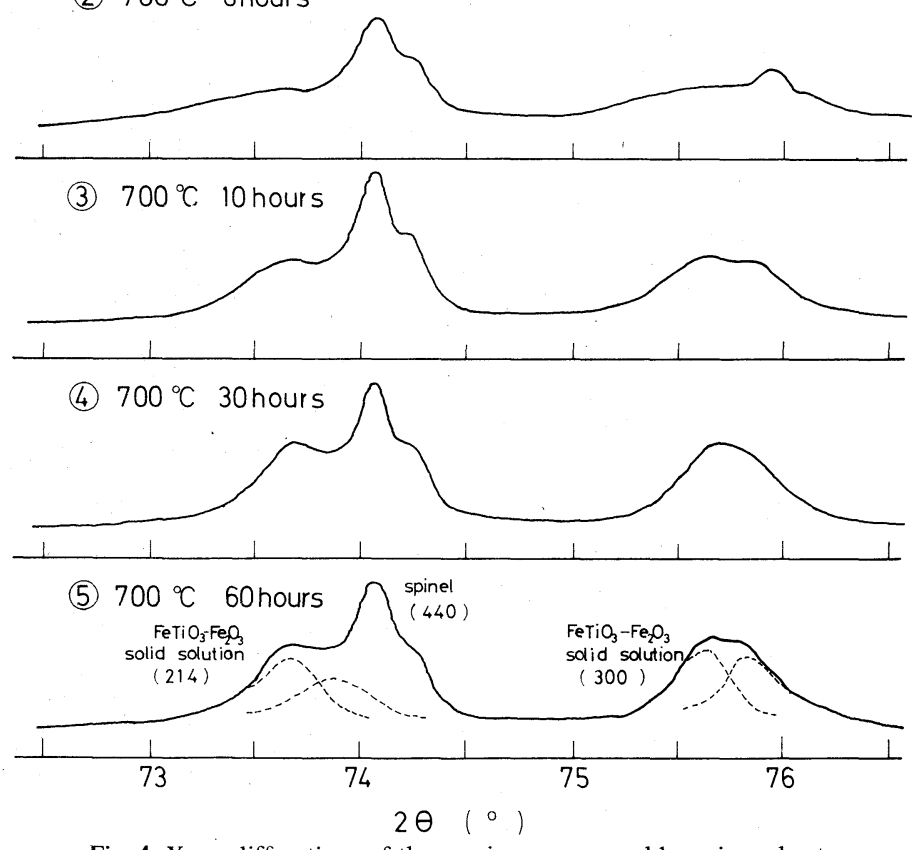

Fig. $4 \mathrm{X}$ ray diffractions of the specimens prepared by vairous heat treatments.
で, 当然のことながら強磁性も認められる。(5)の 60 時間 の焼成により得られたイルメナイトーへマタイト系固溶体 の回折図形を詳細に解析すると同図のごとく完全に一つの 組成にはならなかつた。スピネル相の格子定数は $8.398 \AA$ であり，ほとんどマグネタイト $(8.396 \AA$ ）の格子定数に 一致する。

なお，各焼成時間で得られた試料の磁化を測定した結果， 6 時間の焼成で約 $14 \mathrm{emu} / \mathrm{g}$ の磁化が生じ焼成時間が増す とともに減少するが, 60 時間をへてもなお磁気的に減少傾 向を示していることが認められた。

以上の結果より，イルメナイトーヘマタイト系固溶体の 生成には Fig. 5 に示すように二つの機構が関与しているも のと考えられる。一つはイルメナイトとへマタイトが直接, 固溶体を生成する機構であり，もう一つはイルメナイトが 分解し, マグネタイトとルチルを生成する機構である。前 者の機構についてはUyeda ${ }^{9)}$ や Carmichael ${ }^{8)}$ の報告があ り, これらによれば二つの組成の固溶体が生成する固溶線 の最高 ( 臨界) 温度は $950^{\circ}$ C 付近であり，それ以下では不 固溶組成 (miscibility gap)が存在する。しかし, 著者 らの結果では $800^{\circ}$ Cでも一成分の固溶体が生成し, Lindh の言うように固溶線の最高温度は $700 \sim 800^{\circ} \mathrm{C}$ 以下に存在 するものと思われる。なお $700^{\circ}$ Cで出発組成 $x=0.5,0.6$ の試料を 60 時間焼成しても一つの組成の固溶体とはなら なかつた。また， $x=0.5$ の試料を $1200^{\circ} \mathrm{C}$ で 6 時間焼成 後これを $700^{\circ} \mathrm{C} に 48$ 時間保持しても高温で生成した固溶 体が 2 組成に別れることはなかつた。 これらの結果から，

$700^{\circ} \mathrm{C}$ 以下で尭成するとイルメナイトおよびへマタイトの 構成イオンの拡散が不十分であるため, 反応愹易 に平衡に達しないものと考えられ, 正確な固溶線を 得るためにはより長時間の焼成実験が必要と考えら れる。一方, イルメナイトが分解しマグネタイトと ルチルを生成する機構は $700^{\circ} \mathrm{C} の x=0.2 \sim 0.4$ 付 近で顕著に表われるが，これは次式の反応が進行す るためと考えられる。

$\mathrm{Fe}_{3} \mathrm{O}_{4}+\mathrm{TiO}_{2}=\mathrm{FeTiO}_{3}+\mathrm{Fe}_{2} \mathrm{O}_{3}$

(1)式の反応に伴う生成自由エネルギー変化 $(\Delta G)$ は $900^{\circ} \mathrm{K}$ で+ $1,800 \mathrm{cal}^{15)}$ と符号が正であり, 700 ${ }^{\circ} \mathrm{C}$ 付近では反応は左辺に移行する条件にあると考え

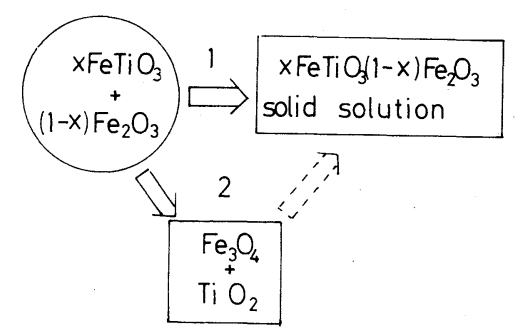

Fig. 5 Schematic diagram of the formation of $\mathrm{xFeTiO}_{3}(1-\mathrm{x}) \mathrm{Fe}_{2} \mathrm{O}_{3}$ solid solution.

d) Pseudo-brook i te 系固溶体は $\mathrm{Fe}_{2} \mathrm{O}_{3}, \mathrm{TiO}_{2}, \mathrm{Fe}$ を化学量論 的に調合し, 䨌囲気を $10^{-3} \mathrm{mmHg}$ とし, 封入法により 1150 ${ }^{\circ} \mathrm{C}, 2$ 時間焼成後急冷すると得られる。13) 本実験条件も Pseudo-brooki te 系固溶体を生成する条件にある。 


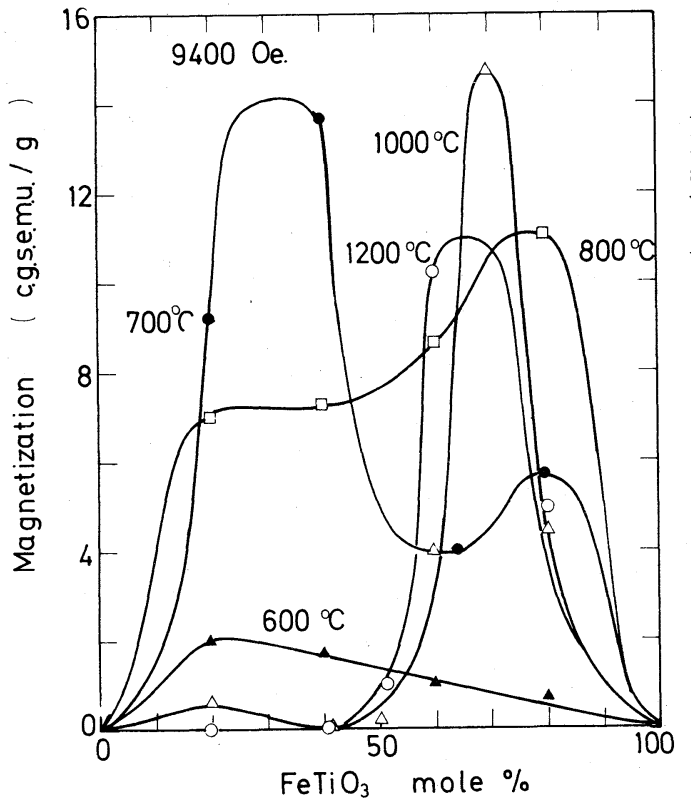

られる。1016) また,一度生成したマグネタイトとルチルも焼 成時間が増すとイルメナイトーヘマタイト系固溶体を生成 するがこの反応は遅く, したがつて $700^{\circ} \mathrm{C}$ 付近ではイルメ ナイトーヘマタイト系固溶体とマグネタイトとルチルが共 存するものと考えられる。

しかし，焼成温度が $800^{\circ} \mathrm{C}$ 以上になるとイルメナイトと ヘマタイトの構成イオンの拡散が十分可能になり, 固溶体 の生成にともなう自由エネルギー変化 $(\Delta G)$ が負に十分大 きくなるため, (1)式の反応に伴う生成自由エネルギー変化 よりも優勢となつて, イルメナイトーヘマタイト系固溶体 が安定に存在するものと考えられる。

つぎに生成物の磁性の測定を行なつた結果をのべる。

Fig. 6 は各温度で 6 時間焼成して得られた焼成物の 9400 Oe.に打ける磁化を出発組成に対してブロットしたもので ある。 $600^{\circ}$ Cで尭成した試料の磁化は $x=0.2$ で最大とな り，イルメナイト組成 $(x)$ が増すにつれ減少する。 $700^{\circ} \mathrm{C}$ で焼成した試料の磁化はイルメナイト組成 $(x)$ が增すとと もに増加し, $x=0.3$ 付近で最大になつた後減少し, $x=$ 0.8 で再び増加する。 $x=0.3$ 付近の高い磁化はスピネル の生成, および $x=0.8$ での比較的高い磁化はイルメナイ トーへマタイト系固溶体の生成に起因寸るものと考光られ る。 $800^{\circ}$ Cで焼成した試料の磁化はいずれの組成でも比較 的高く,イルメナイト組成 $(x)$ が増すとともに増加し $x=$ 0.8 で最大になる。 $700^{\circ} \mathrm{C}$ の場合に比し $x=0.3$ 付近で低 いのは生成したスピネルがこわれているため, および $x=$ 0.8 での高い磁化は $x=0.7$ 付近の高い磁化を示す固溶体

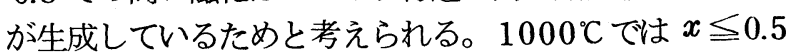
で磁化はほとんど認められないが，イルメナイト組成 $(x)$ が 0.5 を超えると急激に磁化が発生し， $x=0.7$ で最大に なつた後減少する。 $1200^{\circ} \mathrm{C}$ で得た磁化も $1000^{\circ} \mathrm{C}$ の場合

e）混合の自由エネルギー: $n_{A}$ 個の純成分 $A, n_{B}$ 個の純成分 $B$ から置 換型固溶体 $A B$ を生成するときの自由エネルギー変化 $(\Delta G)$ は

$\Delta G=G_{A B}-\frac{n_{A}}{n_{A}+n_{B}} G_{A}-\frac{n_{B}}{n_{A}+n_{B}} G_{B}=\Delta H-T \Delta S$

ただし， $G_{A B}, G_{A}, G_{B}$ は固溶体 $A B$, 純成分 $A, B$ の 1 モルあたりの 自由エネルギー
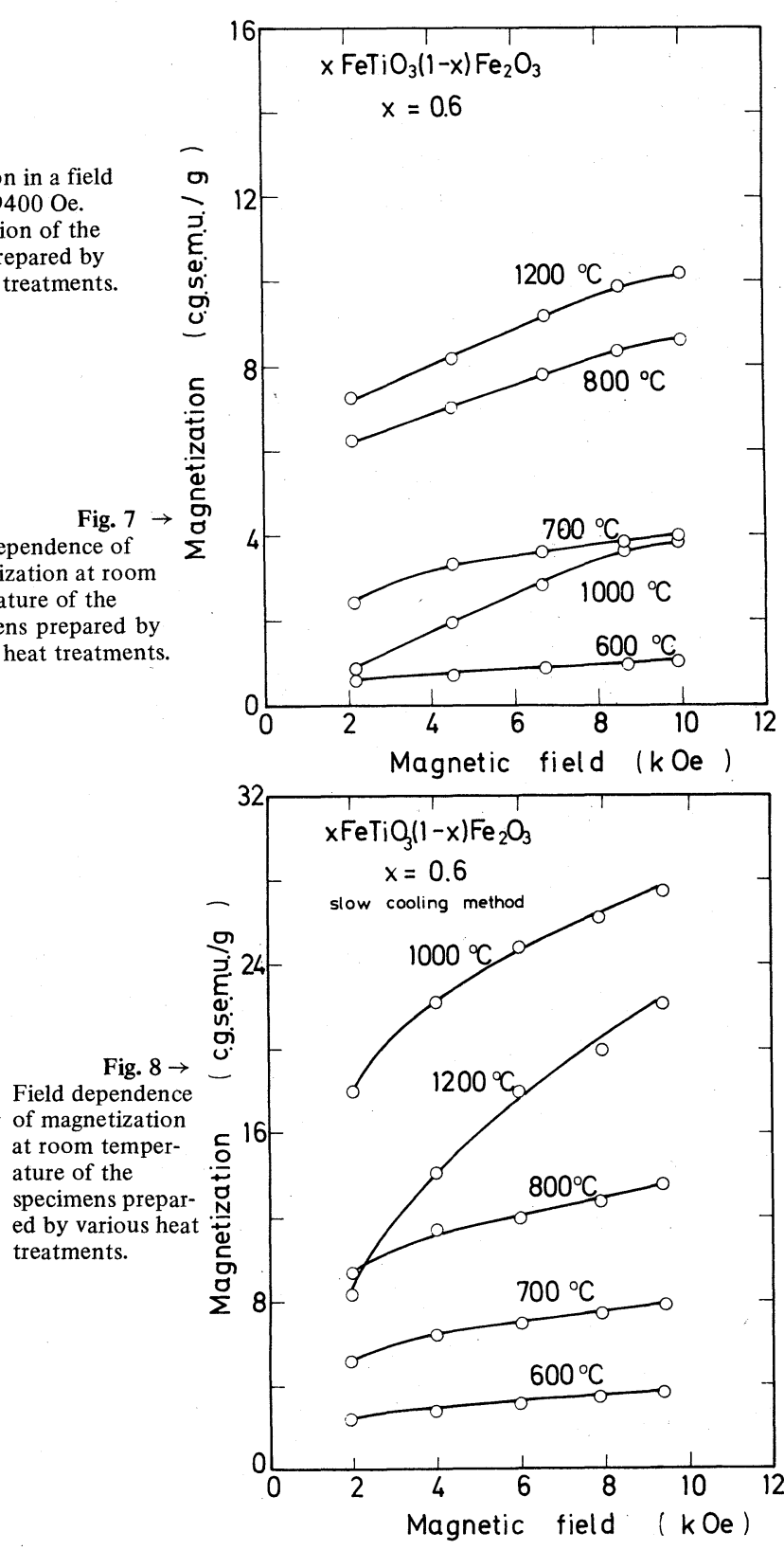

と同様の傾向を示し,イルメナイト組成 $x \leqq 0.4$ で磁化は 認められず $x=0.65$ 付近で最大の磁化を示している。 $1200{ }^{\circ} \mathrm{C}$ にて得られるこのような磁化の変化は以前に Ishikawaらが求めた結果 ${ }^{3)}$ とほぼ一致する。

Fig. 7 は各温度で 6 時間焼成した組成 $x=0.6$ の試料の 磁化曲線を示したものである。いずれの焼成温度で得られ た磁化曲線も磁場が増すとともに飽和する傾向を示す。イ ルメナイトーヘマタイト系固溶体の磁性は熱処理温度に影 響されやすい。これは結晶内の $\mathrm{A}, \mathrm{B}$ 部分格子への金属イ オンの配列の違いによるもので， Fe と Ti が規則配列をし た場合には結晶の対称性はR $\overline{3}$ ，不規則配列をした場合には $\mathrm{R} \overline{3} \mathrm{C}$ をり ${ }^{5)}$ 各熱処理温度により $\mathrm{R} \overline{3}$ から $\mathrm{R} \overline{3} \mathrm{C}$ 内の任意 の配列をとるものと考えられる。 $\mathrm{R} \overline{3}$ は $\mathrm{R} \overline{3} \mathrm{C}$ より低温で安 定となり磁性も強い。いま比較のために $x=0.6$ の試料を 各温度で 6 時間焼成し, 室温まで炉中で放冷した試料の磁 化曲線を Fig. 8 に示した。いずれの焼成温度で得られた磁 化も急冷法で得られた值より高い值を示しており, また, 
$1000^{\circ} \mathrm{C}, 1200^{\circ} \mathrm{C}$ 磁化曲線は同図に示すように飽和して いない。磁化曲線が飽和しない現象はその他 $x \geqq 0.5$ の試 料について $800^{\circ} \mathrm{C}$ 以上から焼成物を放冷しても認められた。 このように放冷法で生成した試料の磁化が急冷法のそれに 比し高いのは, 放冷法の場合, 各試料の磁性が焼成温度よ り低い温度で決定されるためと考えられる。また，磁化不 飽和の現象は生成する固溶体の結晶磁気異方性 ${ }^{16)}$ と関連し ており, 放冷法で生成したイルメナイトーヘマタイト采固 溶体では Fe と Tiの配列が規則化し強い結晶磁気異方性が 生ずることに ${ }^{\mathrm{f})}$ 原因があると推察される。

次のFig. 9, 10はイルメナイトーヘマタイト系固溶体の 磁性と焼成温度の関係を検討した結果である。組成 $x=$ $0.6,0.52$ の試料を $1200^{\circ} \mathrm{C}, 6$ 時間焼成後急冷し, $\mathrm{X}$ 線 回折および磁性の測定を行なつた後, 試料を別のアンプル に入れかえ $600 \sim 800^{\circ} \mathrm{C}$ に適当時間保持 ${ }^{18)}$ し急冷して物性 の測定に供した。Fig. 9 は $1200{ }^{\circ} \mathrm{C}$ で生成した $x=0.6$ の

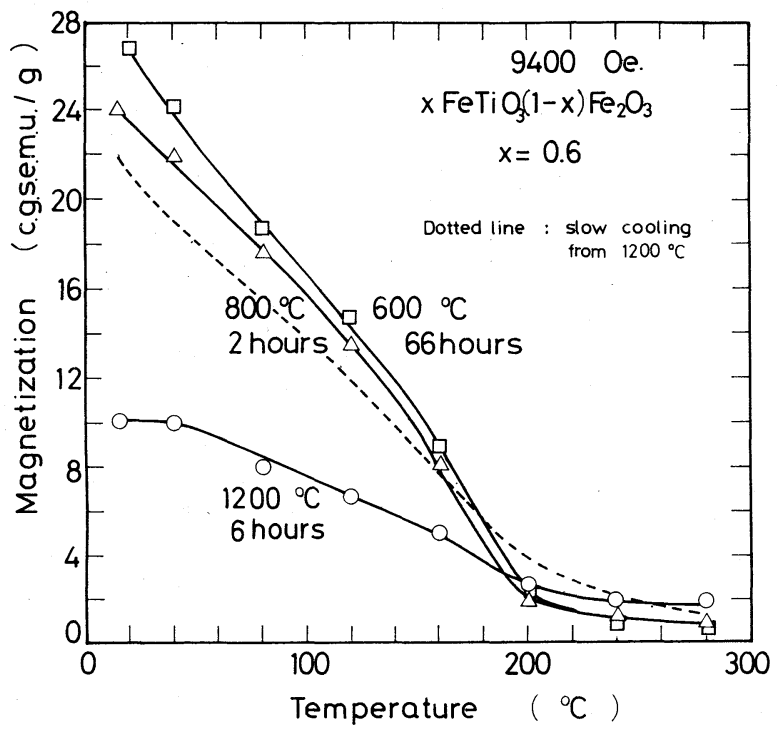

Fig. 9 Thermomagnetic curves of the specimens quenched from various temperatures.

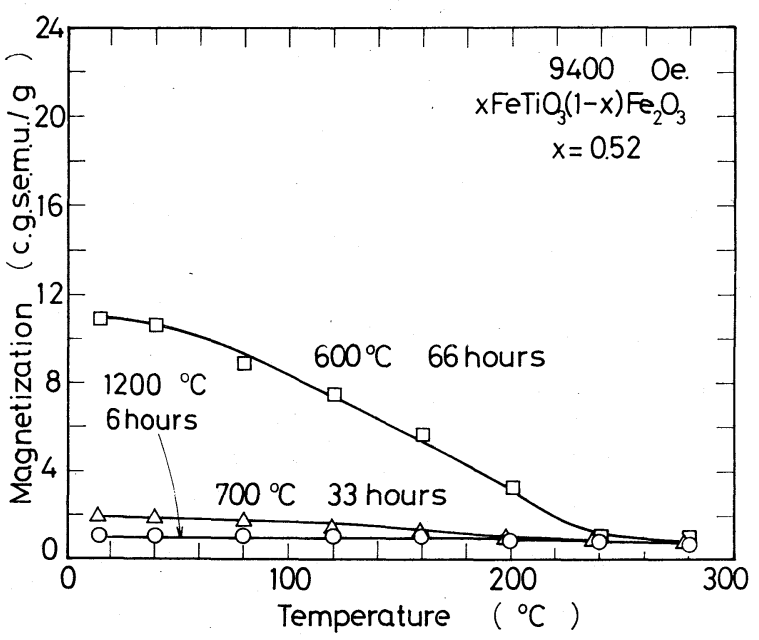

Fig. 10 Thermomagnetic curves of the specimens quenched from various temperatures.

f） $\mathrm{FeTiO}_{3}$ に $10 \%$ 以上 $\alpha-\mathrm{Fe}_{2} \mathrm{O}_{3}$ が加わるとスピソはc 面内を向くた め, $c$ 軸に関して強い磁気異方性を示す。17)
固溶体を $800^{\circ} \mathrm{C}$ で 2 時間および $600{ }^{\circ} \mathrm{C} て ゙ 66$ 時間保持した ときに得られる熱磁曲線を示したもので, 比較のために $1200^{\circ} \mathrm{C}$ で生成した固溶体の熱磁変化および $1200^{\circ} \mathrm{C} よ り$ 放冷して得られた結果を破線で示した。同図に示すように, 固溶体の磁化は $600^{\circ} \mathrm{Cおよび} 800^{\circ} \mathrm{C}$ 適当な時間保持する と増加すること, および $1200^{\circ} \mathrm{C}$ より放冷して得られた固 溶体の磁化は $800^{\circ} \mathrm{C}$ 付近より急冷して得られたものとほぼ 同じ磁化を示すことなどが認められた。 800 Cおよび 600 ${ }^{\circ} \mathrm{C}$ 保持試料のX線回折結果は $1200^{\circ} \mathrm{C}$ 焼成物と差違はなく, 磁化の増加はスピネルの生成ではなく結晶の対称性が改善 されて発生したものであると考えられる。

Fig. 10 は $x=0.52$ の試料を $700{ }^{\circ} \mathrm{C} て ゙ 33$ 時間および $600{ }^{\circ} \mathrm{C}$ で 66 時間保持して得られた試料の熱磁曲線を示し たものである。 $1200^{\circ} \mathrm{C}$ で焼成した試料の磁化はほとんど 認められず, 結晶の対称性はR $\overline{3} \mathrm{C}$ であると考えられる。 かし $700^{\circ} \mathrm{C}$ て熱処理すると磁化が生じ始め, $600{ }^{\circ} \mathrm{C}$ では強 く磁化されている。いずれの焼成試料のX線回折結果にも スピネルおよびルチルを生成した形跡はなく磁化の増加は 温度の低下とともに結晶の対称性が $\mathrm{R} \overline{3} \mathrm{C}$ から $\mathrm{R} \overline{3}$ 移行し ていくためと考えられる。17)

Fig. 11 は $1200^{\circ} \mathrm{C} ， x=0.6$ および $700^{\circ} \mathrm{C} ， x=0.2$ の 6 時間焼成試料の磁化温度特性をみた結果である。前者の キュリー温度は $220^{\circ} \mathrm{C}$ 付近であり, Nagataらが得た值 $135^{\circ} \mathrm{C}$ より高い值を示している。 一方, 焼成温度 $700{ }^{\circ} \mathrm{C}$, $x=0.2$ の試料のキュリ一温度は $580^{\circ} \mathrm{C}$ 付近であり, これ はマグネタイトのそれに近い。すなわち， $x=0.2$ 付近に て得られるスピネルはマグネタイトの生成のためと考えら れ，この結果はX線回折結果 (Fig. 5 )に一致する。

\section{4. 結論}

以上, 人工試料を用いイルメナイトーヘマタイト系固溶 体 $\left(x \mathrm{FeTiO}_{3}\right.$. (1-x $\left.\mathrm{Fe}_{2} \mathrm{O}_{3}\right)$ の生成におよぼす組成および

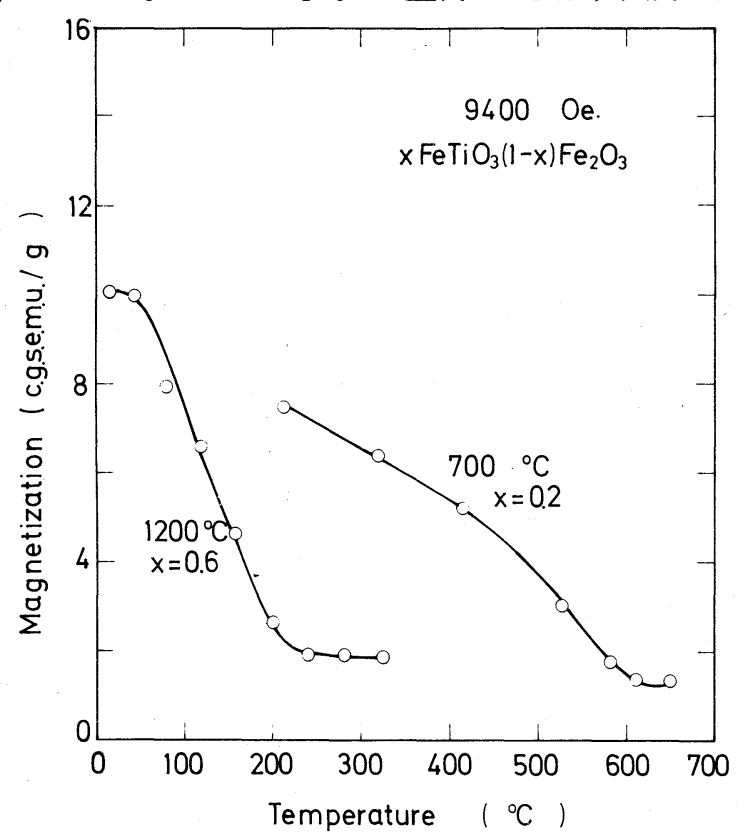

Fig. 11 Magnetization in a field strength of $9400 \mathrm{Oe}$. vs. temperature of the specimens prepared by various heat treatments.

日本鉱業会誌/961114（'80-12）861<5> 
温度の影響を検討した結果をまとめると次のようである。

1) イルメナイトとへマタイトの固溶は $600^{\circ} \mathrm{C}$ 付近から 顕著になり，700〜800 $\mathrm{C}$ で進行する。600〜 700 ${ }^{\circ} \mathrm{C}$ では 広い出発組成に対して二つの組成の固溶体が生成し, それ らは 60 時間焼成しても一つの組成にはならなかつた。べ ての出発組成にわたつて一つの組成の固溶体が得られるの は $800^{\circ} \mathrm{C}$ 以上である。

2) $600 \sim 800^{\circ} \mathrm{C}$ ではイルメナイトーヘマタイト系固溶 体が生成するほかにスピネルとルチルが生成する。この傾 向は特に $700{ }^{\circ} \mathrm{C}$ のルメナイト組成 $(x)$ の小さな $x=0.3$ 付近にて顕著である。このスピネルはマグネタイトと考え られる。

3）イルメナイトーヘマタイト系沽溶体の生成は二つの 機構により行なわれるものと考えられる。一つはイルメナ イトとヘマタイトが值接固溶する機構であり，もう一つは 一度マグネタイトとルチルを生成し, 後にイルメナイトヘマタイト系固溶体を生成する機構である。600 700 $\mathrm{C}$ では前者の反応は起こり難く主に後者の機構によると考え られ、マグネタイトとルチルからイルメナイトーヘマタイト 系固溶体を生ずる反応は非常に遅い。したがつて，この温 度範囲ではイルメナイトーへマタイト系固溶体とマグネタ イトとルチルが共存するものと考えられる。

4) スピネルおよびルチルの混在しないイルメナイトー ヘマタイト采固溶体は $1000^{\circ} \mathrm{C}$ 以上ですべての組成にわたつ て生成する。磁化は $x<0.5$ ではほとんど認められないが, イルメナイト組成 $(x)$ が 0.5 を超えると磁化が発生し, イ ルメナイト組成 $(x)$ が増すとともに急激に増加し $x=0.65$ 付近で最大になつた後減少する。このときの $x>0.5$ の磁 化曲線は急冷法で得たものは飽和するが放冷法で得たもの は外部磁場 $9400 \mathrm{Oe}$.においてもいずれも飽和しなかつた。 これは $\mathrm{R} \overline{3}-\mathrm{R} \overline{3} \mathrm{C}$ 転移によるものと考えられる。

5 ) 高温で作成し急冷した固溶体の磁化はそれを低温で
保持することにより高くなる。放冷法により得られる固溶 体の熱磁特性が急冷法のそれに比し若干高いのはこのため で, 4 ) と同様 $\mathrm{R} \overline{3}-\mathrm{R} \overline{3} \mathrm{C}$ 転移が関係していると推察される。 本研究室を遂行するにあたり有益なご教示を頂いた東北 大学理学部教授石川義和博士, ならびに, 本稿をまとめる にあたり種々ご高配をたまわつた東北大学:選鉱製鍊研究所 教授臼井進之助博士に深謝する次第である。なお, 本研究 は文部省科学研究費 (一般研究 B ) によつた。記して謝意 を表する。

\section{参考文献}

1) T. Nagata: Rock Magnetism, p.75, 1961, Maruzen, Tokyo

2) T. Nagata and S. Akimoto: Geofis. pure e applic., Milano, 34, 36, (1956)

3) Y. Ishikawa and S. Akimoto: J. Phys. Soc. Japan, 12, 1083, (1957)

4) Y. Ishikawa: J. Phys. Soc. Japan, 13, 828, (1958)

5) Y. Ishikawa and S. Akimoto: J. Phys. Soc. Japan, 13, $1110,(1958)$

6) Y. Ishikawa and S. Akimoto: J. Phys. Soc. Japan, 13, $1298,(1958)$

7）平社敬之助·田中時昭・栗原二郎：日本釷業会誌，75，34, (1959)

8) C. M. Carmichael : Proc. Royal Soc. Ser. A., 263, 508, (1960)

9) S. Uyeda: Japan J. Geophys, 2, 1, (1958)

10) A. Lindh: Lithos, 5, 325, (1972)

11) A. Muan, E. F. Osborn: Phase Equili. among Oxide in Steel Making p.28, (1965), Addison-Wesley Pub. Co.

12) G. D. Nicholls: Advanc. Phys. 4, 113, (1955)

13) S. Akimoto, T. Nagata and T. Katsura: Nature, 179, 37,1957

14) J. Verhoogen: J. Petrol, p. 168, (1962)

15) D. H. Lindsley: C. I. W. year book, p.100, No. 1961, ( 1962 )

16）石川義和：磁性物理の進歩, 近角聰信編, p. 332, (1964),・アグネ ( 東京)

17) Y. Ishikawa, Y. Syono: J. Phys. Chem. Solids. 24, 517, (1963)

18) G. Shirane, S. I. Pickart, R. Nathans, and Y. Ishikawa,: J. Phys. Chem. Solid. 10, 35, (1959)

\section{The Fundamental Study on the Formation of Ilmenite-Hematite Series Minerals}

by Junzo SHIMOIIZAKA ${ }^{1}$, Katsuto NAKATSUKA ${ }^{2}$, Susumu TAKEDA ${ }^{3}$ and Shigeru HASEBE ${ }^{4}$

The influence of composition and temperature on the formation of solid solution $\mathrm{xFeTiO}_{3}(1-\mathrm{x}) \mathrm{Fe}_{2} \mathrm{O}_{3}$ were examined, using artificial materials. The mixture of pure ilmenite and hematite, sealed in a quartz tube under evacuated approximately below $10^{-3} \mathrm{mmHg}$, was sintered in a furnace. The results obtained were as follows.

1) Ilmenite and hematite begin to dissolve each other at the temperature above $600^{\circ} \mathrm{C}$. At the temperature range of $600 \sim 700^{\circ} \mathrm{C}$, solid solutions, having two compositions, were formed over the wide range of the initial compositions. These solid solutions did not turn into a single composition even after sixty hours of sintering. Solid solutions, having the single composition, were formed above $800^{\circ} \mathrm{C}$.

2) At the temperature range of $600 \sim 800^{\circ} \mathrm{C}$, spinel and rutile were formed with $\mathrm{xFeTiO}_{3}(1-\mathrm{x}) \mathrm{Fe}_{2} \mathrm{O}_{3}$. solid solutions. This phenomenon was most obvious at $700^{\circ} \mathrm{C}$ and about $\mathrm{x}=0.3$. This spinel was identified as magnetite.

3) There were two mechanisms to form $x \mathrm{FeTiO}_{3}(1-\mathrm{x}) \mathrm{Fe}_{2} \mathrm{O}_{3}$ solid solution. One is the formation of $x \mathrm{FeTiO}_{3}(1-\mathrm{x}) \mathrm{Fe}_{2} \mathrm{O}_{3}$ solid solution from the mixture of ilmenite and hematite. The other is the formation of magnetite and rutile from the mixture of ilmenite and hematite, followed by the formation of $\mathrm{xFeTiO}_{3}(1-\mathrm{x}) \mathrm{Fe}_{2} \mathrm{O}_{3}$ solid solution. The former was remarkable at the composition of $x \geqq 0.6$ and the latter was remarkable at the composition of about $\mathrm{x}=0.3$.

4) Solid solution $\mathrm{xFeTiO}_{3}(1-\mathrm{x}) \mathrm{Fe}_{2} \mathrm{O}_{3}$, excluding magnetite and rutile, are formed over the whole range of compositions at the temperature above $1000^{\circ} \mathrm{C}$. The magnetization increased with the decrease of $x$, reaching the maximum at $\mathrm{x}=0.65$ and then decreased. The magnetization of solid solution with the composition $\mathrm{x}<0.5$ was very small, while the solid solution with the composition $x \geqq 0.5$ showed ferrimagnetism. The magnetization curves of the latters was saturated but that of solid solutions $(x \geqq 0.5)$ prepared by slow cooling method was not saturated even at 9400 Oe.

5) When solid solution $\mathrm{xFeTiO}_{3}(1-\mathrm{x}) \mathrm{Fe}_{2} \mathrm{O}_{3}$ formed at $1200^{\circ} \mathrm{C}$ was maintained at lower temperature for appropriate time, the magnetization increased. Therefore the magnetization of solid solution obtained by the slow cooling method is higher than that of solid solution obtained by the quenching method.

(1. Prof., Dr., Faculty of Engineering, Tohoku Univ. 2. Assoc. Prof., Dr., Faculty of Engineering, Tohoku Univ. 3. Assist., Research Institute of Mineral Dressing and Metallurgy, Tohoku Univ.

Engineering, Iwate Univ. 